\title{
Intellectual Growth and the Integration of the Study Abroad Experience
}

Brian Hoyer' story is not a typical one, but it is exemplary. Brian was one of the first International Studies majors at Middlebury College with a track in African Studies. His disciplinary concentration was Anthropology and his language Kiswahili. The research for his prize-winning senior thesis, on which his article in this magazine was based, was undertaken in Tanzania during the summer of 2003, with the support of a grant from the Felix Rohatyn Center for International Affairs at Middlebury College. However, this was not Brian's first visit to Africa: he had previously spent six weeks in Kenya with Experiment for International Living, three months in Ghana doing survey research and teaching in a neighborhood school, and two weeks on a relief mission to Mozambique. But the inspiration for his senior thesis research in Tanzania came from his study abroad with School for International Training's Development Studies Program in Uganda in spring 2002 where his independent project involved the study of refugee strategies of self-reliance. This led to further travel in Rwanda and Tanzania, a refugee simulation project back at Middlebury, and his independent research among Congolese refugees in Tanzania_-all of which culminated in his senior thesis. Since graduation in February 2004, Brian has been working in the Africa section of the AmeriCares Foundation, which specializes in providing medical assistance to those in need, thus enabling him to continue and deepen his involvement with the African continent as he contemplates his future.

Integral to the successful undergraduate experience is the intellectual growth that takes place as students begin to pursue their own lines of academic inquiry. While the process varies from student to student, what is common to many of them, in particular those who study abroad, is the very personal and often intense discovery of what the academic project is all about. Over and over again, one reads in the evaluations of returning students how they became inspired by the academic independence granted by overseas institutions or how their academic studies came alive for the first time because of the physical proximity the students had to their subjects. Brian Hoyer is just such a case in point.

While study abroad for a semester or an academic year is, to be sure, the culmination of the liberal arts experience, in the sense that it extends the student's discovery of worlds outside the one grown up in to other countries, 
as well as the culmination of the process of developing perspective on all of the student's worlds-personal, familial, home town, school, college, and country - in recent years study abroad professionals and faculty have talked more and more about achieving a better integration of study abroad with the academic program at the home college or university. Today, this goal is subsumed by the term "curriculum integration," and in its most mundane form can simply involve students taking courses abroad that are the same as what they can take at home and sometimes even taught by instructors from the home school. Other versions, regrettably few, may involve "re-entry" programs or one-credit re-entry courses and, even more rarely, a full threecredit course that seeks to take direct advantage of the students' time abroad and encourage the processing of that experience through research conducted in the college library on their return. At my own college, we have established a series of team-taught, interdisciplinary, and cross-regional, senior seminars that brings International Studies majors from a variety of regional backgrounds together, enabling them to apply their different experiences abroad to a common topic of study.

However, what we are concerned with in Brian Hoyer's case is a very different form of curriculum integration - arguably the highest form. For a long time, faculty have considered study abroad in the junior year an excellent opportunity for the motivated undergraduate to take advantage of the unique sources and materials available abroad and begin research for a thesis that would be completed during their senior year on return to the US. Regretfully, this does not happen as often as it might, in part, perhaps, because a busy faculty understandably do not always push this opportunity as forcefully as they might, since, overburdened as they are, they do not have the time to guide such research from afar. Nonetheless, just as the senior thesis or project is seen by both faculty and students as the culmination of a student's four years in college, it seems to this author that undertaking research while studying abroad that can be combined with the appropriate literature on return home and turned into a research paper or senior thesis represents the epitome of the liberal arts experience and ties together or "integrates" in the most complete way the student's time abroad with the home school curriculum, taking the academic experience to new levels.

This interaction of study abroad and academic coursework at home can take several forms. For some, the experience abroad might lead them to undertake senior thesis research while still abroad. For others, their newly awakened awareness and excitement motivates them to use the knowledge and 
experience gained abroad to begin a senior thesis on their return. When looked at in terms of the final outcome, these students are widely regarded as those who have gained the most from their time abroad. While it may or may not be the case that these students have gained the most, it is true that they are also usually the ones who apply for and receive the majority of Fulbrights, Watsons, and other post-graduate scholarships. Regardless, the strong connection that develops between these students and their topics frequently entices them to return to the country or region that first attracted them in order to conduct further study and/or research, either while still an undergraduate, as was the case with Brian, or following graduation. Thus has this special issue of Frontiers chosen to focus on some of the very best students who conducted research while studying abroad, or who returned following study abroad prior to their senior year to conduct research, or who were inspired by their time abroad to undertake a senior thesis. I hope this enables readers to see some of the wonderful academic benefits that can come when study abroad and the students' home curriculum are integrated through research conducted during an extended period of study abroad.

\section{D a v i d M a c e y}

Director, Off-Campus Study

Professor of History, C.V. Starr Professor of Russian Studies

Middlebury College 